\title{
Teaching through lectures and achieve active learning in higher education
}

\author{
Valentina Haxhiymeri (Xhafa), PhD \\ Department of Psychology \\ Educational Science Faculty, Elbasan University, Albania \\ Florinda Kristo , PhD \\ Department of Teaching Methodology \\ Educational Science Faculty, Elbasan University, Albania
}

DOI:10.5901/mjss.2014.v5n19p456

\begin{abstract}
Effective teaching is vital for student learning in higher education. The purposes of this study were to explore what makes a lecture to be able to promote active learning of students, and to measure by means of questionnaires (Course Questionnaire based on the principles of good teaching; Survey of classroom teaching methods) the teaching effectiveness through large group lecture in terms of using active learning strategies. Apropos, it was asked 300 students and 8 lecturers from varied disciplines of Elbasan University, in Albania, that to complete individually a questionnaire. The questionnaire considered key aspects of an effective lecture prescribed by current research, such as generating and maintaining interest, student engagement, organization and structure. The results of study showed that a considerable part of lectures, in particularly new lectures, were using Power Point presentations frequently and with long sequences of slides which contained a lot of listed information. Also, the students reported difficult for the new lectures to manage disruptive behavior in the auditorium. The study concluded that teaching through lectures and achieve active learning in higher education is a challenging experience for the new lecturers. The study remarked that academics are prepared for their role as research, but not their teaching duties. But, teaching in university is not an activity that anyone can do. Getting the lecture right is a skill and can take time. Furthermore, findings recommended that it is very important providing for a substantial investment into enhancing the teaching abilities of in-service academic staff and starting for preparation of university teachers.
\end{abstract}

Keywords: Teaching and learning in higher education, challenges for new lecturers, university teacher.

\section{Introduction}

Background on lectures and active learning in higher education

Effective teaching is vital for student learning in higher education. As a platform for disseminating ideas and knowledge and for guiding and motivating students, teaching through lectures continue to be a cornerstone of higher education practices today. A further reason that lectures continue to remain important part of the university teaching and learning experience is also the significant growth in student numbers during recent decade. In this situation lecturing to large groups of students seemingly is utility solution for many higher education institutions.

Traditionally, lectures have involved the one-way transmission of course content from academics to students. This teachercentered lecture format where professor talks for an hour or more and students listen is not an efficient means of conveying information and succeeding to students. According to Richard M. Felder (2007), student concentration rises sharply in the first ten to fifteen minutes of a lecture but then falls off sharply for the rest of the hour.1 Other researchers have evidenced that the average number of items that can be held in short-term memory is $7( \pm 2)$. Therefore, if students do not have significant time to process new information, one of two things happens: either previous information is displaced or the new information is lost. Lectures that proceed quickly simply do not give students sufficient time to process information. 2

However, lectures have more than a mere dissemination role. They should also motivate and challenge students and give them insights. Lectures would provide key opportunities for students to learn in an efficient way about the subject they have

1 Felder, R. (2007)

2 John Sloman; Chris Mitchell; Peter Davies (2002) 
chosen to study. The lectures could typically convey and prioritise information about the subject in a relatively condensed format. It can also enthuse to students and provide a suitable framework for further study. 1

Typically, the lecture is defined as the delivery of a course through a series of presentations by academic staff members to a group of students, usually with visual prompts and aids. 2 However, most university teachers rely more on a generic understanding than a certain definition for lecture. They bring to the lecture theatre their experience of teaching in different approaches which often are based on inbuilt informal theories. 3 These theories which may be either consciously stated or implied in what the lecturers do in auditorium, have implications for the students learning process, their attitudes and academic achievement.

There is significant research literature which discusses about ways of making lectures more effective and able to promote much more students' learning than simply to transmit information. Many of them suggest modifying traditional lectures 4 and incorporating active learning in classroom as an instructional method that engages students in meaningful learning activities 5 or involve them in doing things and thinking about what they are doing. 6

Active learning shifts the focus from the teacher and delivery of course content to the student and active engagement with the material. Through active learning techniques and modeling by the teacher, students shed the traditional role as passive receptors and learn and practice how to apprehend knowledge and skills and use them meaningfully. 7

According to Ann Morton (2009)8 a lecture promoting active learning should have the following attributes:

It is delivered in a way that is informative, interesting and engaging.

The content is well organized, easy to follow and structured in a logical fashion.

Students feel involved through some type of active participation, no matter what the class size.

Students leave wondering where the time of lecture has gone.

Students leave knowing that they have learned something(s), and are often inspired to go off and find out more.

As Charles C. Bonwell (2000)9 some of the major characteristics of lecturing associated with active learning strategies include:

Students are involved in more than passive listening,

Students are engaged in activities (e.g., reading, discussing, writing),

There is less emphasis placed on information transmission and greater emphasis placed on developing student skills,

There is greater emphasis placed on the exploration of attitudes and values,

Student motivation is increased (especially for adult learners),

Students can receive immediate feedback from their instructor,

Students are involved in higher order thinking (analysis, synthesis, evaluation)

Thus, active learning involves providing opportunities for students to meaningfully talk and listen, write, read, and reflect on the content, ideas, issues, and concerns of an academic subject. ${ }^{10}$

- Barriers to incorporating active learning into lectures to large student groups

\footnotetext{
1 John Sloman; Chris Mitchell; Peter Davies (2002)

2 John Sloman; Chris Mitchell; Peter Davies (2002)

3Bonwell, Charles C., and James, A. Eison (1991)

4 Penner (1984)

5Prince, Michael (2004)

${ }^{6}$ Bonwell, Charles C., and James A. Eison (1991)

7 Instruction at FSU Handbook (2011)

${ }^{8}$ Ann Morton (2009)

${ }^{9}$ Charles C. Bonwell (2000)

${ }^{10}$ Meyer, C., \& Jones, T.B. (1993)
} 
- The recent research in field has identified some potential barriers 1 or certain specific obstacles 2 that could interfere with implementing active learning in large lecture classes, such as:

- The powerful influence of educational tradition,

- The discomfort and anxiety that change creates,

- The limited incentives for faculty to change

- The difficulty in adequately covering the assigned course content in the limited class time available,

- A possible increase in the amount of preparation time,

- The difficulty of using active learning in large classes;

- A lack of needed materials, equipment, or resources to support active learning approaches,

- The risks that students will not participate or they could resist non-lecture approaches,

- Use higher-order thinking,

- Faculty members will feel a loss of control,

- $\quad$ Lack necessary skills for implementation of active learning strategies.

\section{Methods}

\section{The aims of the study}

To explore relevant research literature about what makes a lecture to be able to promote active learning of students.

To measure by means of questionnaires (Course Questionnaire based on the principles of good teaching; Survey of classroom teaching methods) the teaching effectiveness through large group lecture in terms of using active learning strategies.

\section{Participants}

Participations in this study are students and university teachers/lecturers in Educational Science Faculty of Elbasan University (UE), which was asked to complete personally a questionnaire in order to measure aspects of the quality of teaching and active learning in frame course. The study was executed in the end of term-time (June, 2014) that corresponded with closure of a study course/matter.

The Students' Evaluation of Educational Quality (SEEQ) was distributed to a sample of 300 students from 11 different classes/courses. All the students were in the first year of the study program "Master in Teacher" for varied specialty disciplines, in Educational Science Faculty of Elbasan University, in Albania. On purpose students were not feeling under pressure to their participation in the evaluating process, most of them asked to fill up questionnaires during class time when they were in the end of last lecture of a group course/matter or when they had given a finite examination. The representative of the class was dependent on attendance levels and also how many students were present on that day. According to Study Program Regulation of this Faculty, the lecture is a component of pedagogic system that students ' frequentation could be facultative.

A Survey of Classroom Teaching Methods was issued to a sample of 8 lecturers with full time which delivered on different class subjects to students of the study program "Master in Teacher" for varied specialty disciplines, in Educational Science Faculty of Elbasan University, in Albania. The lecturers were asked to describe the teaching strategies had used last time in class during a large group lecture. 


\section{Instrumentation}

Student evaluations of teaching (SET) are the most common source used in the evaluation of teaching in higher education (Hoyt and Perera, 2000). Five of more mentioned questionnaires with internationally validity in use in higher education, are as follows:1

- The Students' Evaluation of Educational Quality (SEEQ);

- The Course Experience Questionnaire (CEQ);

- The Module Experience Questionnaire (MEQ);

- The Postgraduate Research Experience Questionnaire (PREQ); and

- The Experiences of Teaching and Learning Questionnaire (ETLQ).

To provide higher validity of study findings it was selected to use the Students' Evaluation of Educational Quality (SEEQ). This questionnaire was developed at first by Prof. Herbert Marsh (a psychometrics expert at the University of Western Sydney) and is used to evaluate the teaching quality of individual course modules. Its validity and reliability have been confirmed internationally (Marsh and Roche, 1992). Also, Coffey and Gibbs (2001) 2 and Richardson (2005) 3 have provided a comprehensive discussion of the psychometric properties and discussed the relevance of the SEEQ to Higher Education. Meanwhile, Balam and Shannon (2010) reported that the SEEQ has received recognition for producing valid and reliable scores across different countries such as Hong Kong, Australia, Papua New Guinea, Spain, China and India. In short, SEEQ is an approach with internationally validity and very widely used in universities.

Students respond (anonymously), using a five-point Likert-type scale ranging from Strongly Disagree ("very poor") to Strongly Agree ("very good"), to 29 closed-ended statements exploring teaching effectiveness, which are based on eight dimensions of effective teaching (Marsh, 1984), namely: learning/value, enthusiasm, organization, group interaction, individual rapport, breadth of coverage, examinations and assignments. Space is provided on the instrument for openended and other additional items to be included where required. Completion time is approximately 20 minutes. This instrument is best used with a group of more than 10 students, as with fewer than 10, the reliability decreases.

The student questionnaire is only one means of evaluating and gaining useful feedback about the effectiveness of course lectures. Another valuable means of evaluating of lecture quality is self-assessment on the lecturer/staff. For study aims it was selected to use A Survey of Classroom Teaching Methods (SCTM) to staff which was elaborated by Charls C. Bonwell (2000).4 This survey was made up to help the university teachers to identify in personal level using of active learning strategies during their lectures. The Survey of Classroom Teaching Methods contained 20 items which relate to interactive teaching strategies that a lecturer has used most often last times he/she has taught in a class. Lecturers of Faculty were required to note / indicate with a check mark (from 0 to 3 ) if they had used this teaching method the last time of their lecturing in a large class. Completion of this survey form usually takes 5-10 minutes.

\section{Data collection procedure}

As research literature in the field has recommended, the SEEQ was administered as near as possible to the final week of the course module. Thus, questionnaires was handed out students before the end of second semester and administrated by someone of leading staff and no the teacher of the group. Because of possible problems that Albania has yet with online system, the students asked to complete questionnaire in a handout paper form. At the same way SCTM is administrated to lecturers.

\footnotetext{
1 Elaine Keane \& lain Mac Labhrainn (2005)

${ }^{2}$ Coffey, M. \& Gibbs, G. (2001)

${ }^{3}$ Richardson, J.T.E. (2005).

${ }^{4}$ Charles C. Bonwell (2000)
} 


\section{Data analysis}

The data of paper questionnaires of students (SEEQ) were transferred on to a single grid in order to make it easier to interpret and store the responses. The answers to a question are represented on the questionnaire as points on a scale from 0 (Not Applicable), 1 (Strongly Disagree) to 5 (Strongly Agree). After the data processing, they were analyzed to generate the needful statistic for aims of study. Mean scores were calculated and standard deviation was used to measure variability.

To explain the variation of mean scores regarding level of effectiveness of lecture/performance of lecturer based on students ' evaluation, all mean scores collected for every question were compressed in eight categories, such as: Learning, Enthusiasm, Organization, Group Interaction, Individual Rapport, Breadth, Examinations and Assignments. The rating of maximal and minimal level of effectiveness of lectures/performance of lecturers to every category was as follows:

\subsection{5 - 5.00: excellent performance}

4.50 - 4.74: very good performance

4.25 - 4.49: good performance

4.00 - 4.24: satisfactory performance

3.75 - 3.99: marginal performance

1.00 - 3.74: unsatisfactory performance

To evaluate answers to open questions which were in the end of every CEEQ questionnaire, responses/comments of students were reviewed into two categories as an overall evaluating of lecture: strong points and weak points.

To exploring correlations in the data collected from The Survey of Classroom Teaching Methods (SCTM) it was also created a single grid where it were listed 20 items related to interactive teaching strategies and the responses indicated with a check mark from each lector which was coded based on the length of time he/she had been in post as a lector ( $\mathrm{N}=$ lector; $1 \mathrm{y}=1$ year in post as a lector, 1.8y = 1 year and 8 months in post as a lector, and so on., Thus, e.g., N15y = a lector had been in post 15 years)

Finally, the data processed were sum up on behalf of study purpose to reveal what kind of interactive strategies were used more in lecture with large class (the frequency of using of an interactive teaching strategy during lecturing).

\section{Demographic information}

\section{Students}

A sample of 300 students, in the first year of the study program "Master in Teacher" for varied specialty disciplines, in full time system, in Educational Science Faculty of Elbasan University, in Albania

Average age $=22.7$ old years

Gender: 204 females (68 \%) and 96 males (32\%)

\section{Lecturers}

The sample of 8 lecturers from different departments (mainly from study fields such as, math, linguistics, philosophy, social science) which teach with full time in study programs "Master in Teacher" for varied specialty disciplines.

Average age $=41.3$ old years

Gender: 5 females (62.5\%) and 3 males 37.5$)$

Qualifications: 2 of them hold the title "Professor", 2 hold the grade PhD, 4 are in doctorate process;

University teacher experience: Range: 2.3 years - 18 years; $50 \%$ of the staff had been in this post over 15 years, $12.5 \%$ had been in this post at least 10 years and $37.5 \%$ of the sample had been in less than 5 years. 


\section{Results and Discussion}

\section{Students' perception of the effectiveness of teaching through lecture}

In the table 1 is summarized the statistical information of the students respondents measured by means of CEEQ questionnaire of effectiveness of teaching through lecture. There are mean scores and standard deviation that enable to measure variability of students 'perception of eight of the key dimensions the effective teaching through lecture, such as: Learning, Enthusiasm, Organization, Group Interaction, Individual Rapport, Breadth, Examinations and Assignments.

Although, CEEQ contained questions related directly to key aspects of an effective lecture in frame of a module/subject, at the same time it implied that these questions were related indirectly to the qualities and skills of the lecturer too. Thus, in the table 1 is presented the overall rating of lecture's effectiveness that it also implied lecturer's performance. The lower level of performance is recapitulated in "unsatisfactory" and the higher one is précised "excellent performance".

Table 1: Mean Scores, Standard Deviations and Overall Rating of every Dimension of Effective Teaching/Lecture measured CEEQ

\begin{tabular}{|l|l|l|l|l|}
\hline No. & $\begin{array}{l}\text { Dimensions of effective } \\
\text { teaching/lecture }\end{array}$ & Mean & Standard Deviation & Overall Rating \\
\hline $\mathbf{1}$ & Breadth & 4.58 & 0.17 & very good \\
\hline $\mathbf{2}$ & Learning & 4.50 & 0.15 & very good \\
\hline $\mathbf{3}$ & Assignments & 4.33 & 0.14 & good \\
\hline $\mathbf{4}$ & Organization & 4.25 & 0.14 & good \\
\hline $\mathbf{5}$ & Examinations & 4.21 & 0.16 & satisfactory \\
\hline $\mathbf{6}$ & Group interaction & 4.00 & 0.11 & satisfactory \\
\hline $\mathbf{7}$ & Individual rapport & 3.83 & 0.13 & marginal \\
\hline $\mathbf{8}$ & Enthusiasm & 3.75 & 0.12 & marginal \\
\hline
\end{tabular}

According to the data presented in Table 1, results that none of the items surveyed in this study related to dimensions of effective teaching/lecture, were given a rating equivalent to "excellent".

The maximum achieved in rating of lecture/lecturer performance it was 4.58 mean scores accorded to Breadth dimension which corresponded to "very good" rating. This level is pursued Learning dimension with 4.50 mean scores which was quoted also "very good". Assignments and Organization are sorted on "good" rating to 4.33 and 4.25 mean scores. The Examinations and Group Interaction were rated on "satisfactory" with 4.21 and 4.00 mean scores.

The minimum was found out 3.83 and 3.75 mean score accorded to Individual rapport and Enthusiasm corresponding to "marginal performance".

These findings seem to be consistent with students` additional comments noted down CEEQ (Table 2) such as strong and weak points of lecture/lecturer performance. The strong points related to two teaching dimensions which were rated "very good" such as breadth and learning. Meanwhile weak points related mainly to individual rapport and enthusiasm of lecturers which were rated to "marginal performance".

Table 2: Students ' additional comments in CEEQ

\begin{tabular}{|l|l|l|}
\hline No. & Strong points: & Weak points: \\
\hline $\mathbf{9}$ & $\begin{array}{l}\text { Clear explanation; } \\
\text { Breadth of knowledge; }\end{array}$ & $\begin{array}{l}\text { Few interest to student`s concerns; } \\
\text { Poor management of student` behavior problems; }\end{array}$ \\
\hline
\end{tabular}


Integrating the theory to practice;
Exceedingly using of presentations in Power Point and long sequences of slides which contain a lot of listed information.

There are a few unnecessary modular subjects that overload the study program.

Generally, the students seem to be agree that their lecturers had fulfilled their job in "very good" and "good" rating to such items as research/discipline's breadth of covering and students' learning process, and also to assignments and organization's dimensions.

However, some of items related to individual rapport towards students and their enthusiasm to teach and to provide guidance to them, were estimated lower than all.

Indeed, these findings were being suddenness for this study and would demanded further research to find out the eventual factors which have impacted on lecturers' attitudes as badly as they could be disconcerted in their mission as educators.

\section{The using of interactive teaching strategies during lecturing}

Based on information collected from SCTM, the study showed that even if a limited group in number (the sample of 8 lecturers), among lecturers were found a variety attitudes toward the using of interactive teaching strategies during lecturing, which could be affected from different factors, such as, qualification, years of university teaching experience, difference of the age, different research fields, etc.

Indeed, these factors have not been object of this study, but they were taken into consideration to explore the correlations in the data collected from The Survey of Classroom Teaching Methods (SCTM). Below there is the Table 3 which has served as a single grid to data processing. Thereon, the data were transferred to the Table 4 in a summarized rating.

Table 3: The frequency of using of an interactive teaching strategy during lecturing based on SCTM.

\begin{tabular}{|c|c|c|c|c|c|c|c|c|c|c|}
\hline No. & Interactive Teaching Strategy & $\begin{array}{l}\mathrm{N} \\
1.8 \\
\mathrm{y}\end{array}$ & $\begin{array}{l}N \\
3 y\end{array}$ & $\begin{array}{l}N \\
4 y\end{array}$ & $\begin{array}{l}N \\
10 y\end{array}$ & $\begin{array}{l}N \\
16 y\end{array}$ & $\begin{array}{l}N \\
18 y\end{array}$ & $\begin{array}{l}N \\
21 y\end{array}$ & $\begin{array}{l}N \\
30 y\end{array}$ & $\begin{array}{l}\text { Frequency } \\
\text { of using of } \\
\text { teaching } \\
\text { strategy in } \\
\text { total }\end{array}$ \\
\hline 1 & $\begin{array}{l}\text { I lectured during the entire class } \\
\text { period }\end{array}$ & 2 & 2 & 3 & 1 & 3 & 2 & 3 & 2 & 18 \\
\hline 2 & $\begin{array}{l}\text { I showed a film or video for the } \\
\text { entire class period. }\end{array}$ & 0 & 0 & 0 & 1 & 0 & 0 & 0 & 0 & 1 \\
\hline 3 & $\begin{array}{l}\text { During lecture, I gave a short, } \\
\text { ungraded quiz to check student } \\
\text { comprehension of material }\end{array}$ & 0 & 0 & 0 & 2 & 0 & 0 & 0 & 1 & 3 \\
\hline 4 & $\begin{array}{l}\text { I assigned a short writing activity } \\
\text { without having class discussion } \\
\text { afterward (e.g., writing end-of- } \\
\text { class summaries, providing } \\
\text { questions over material) }\end{array}$ & 0 & 0 & 0 & 0 & 0 & 0 & 0 & 0 & 0 \\
\hline 5 & $\begin{array}{l}\text { I had students complete a survey } \\
\text { instrument }\end{array}$ & 0 & 0 & 0 & 0 & 0 & 0 & 0 & 0 & 0 \\
\hline 6 & $\begin{array}{l}\text { I had students complete a self- } \\
\text { assessment activity (e.g., } \\
\text { complete a questionnaire about } \\
\text { their beliefs, values, behaviors) }\end{array}$ & 0 & 0 & 0 & 0 & 0 & 0 & 0 & 0 & 0 \\
\hline
\end{tabular}




\begin{tabular}{|c|c|c|c|c|c|c|c|c|c|c|}
\hline 7 & I took the class on a field trip & 1 & 0 & 0 & 1 & 0 & 1 & 0 & 0 & 3 \\
\hline 8 & $\begin{array}{l}\text { I assigned a laboratory exercise } \\
\text { that was done by students }\end{array}$ & 0 & 0 & 0 & 0 & 0 & 0 & 0 & 0 & 0 \\
\hline 9 & $\begin{array}{l}\text { I lectured with at least } 15 \text { minutes } \\
\text { of time devoted to recitation or } \\
\text { asking questions designed to } \\
\text { check student understanding of } \\
\text { material (interaction between } \\
\text { teacher-student/student-teacher) }\end{array}$ & 1 & 1 & 1 & 3 & 1 & 1 & 1 & 1 & 10 \\
\hline 10 & $\begin{array}{l}\text { I led a class discussion focused } \\
\text { on a visual/audio stimulus (e.g., a } \\
\text { picture, cartoon, graph, song) }\end{array}$ & 2 & 2 & 2 & 2 & 1 & 1 & 1 & 1 & 12 \\
\hline 11 & $\begin{array}{l}\text { I had students engage in a } \\
\text { brainstorming activity(i.e., a } \\
\text { group activity designed to } \\
\text { generate as many ideas as } \\
\text { possible) }\end{array}$ & 2 & 2 & 2 & 3 & 1 & 2 & 2 & 2 & 16 \\
\hline 12 & $\begin{array}{l}\text { I lectured with at least } 15 \text { minutes } \\
\text { of time devoted to class } \\
\text { discussion (interaction between } \\
\text { student-student, with occasional } \\
\text { questions/remarks by teacher) }\end{array}$ & 1 & 1 & 1 & 1 & 0 & 1 & 0 & 1 & 6 \\
\hline 13 & $\begin{array}{l}\text { I assigned a short writing activity } \\
\text { that was followed by at least } 15 \\
\text { minutes of class discussion }\end{array}$ & 0 & 0 & 0 & 0 & 0 & 0 & 0 & 0 & 0 \\
\hline 14 & $\begin{array}{l}\text { I assigned an in-class reading } \\
\text { activity that was followed by a } \\
\text { significant class discussion } \\
\text { lasting } 15 \text { minutes or more }\end{array}$ & 0 & 0 & 0 & 0 & 0 & 0 & 0 & 0 & 0 \\
\hline 15 & $\begin{array}{l}\text { I assigned a small group } \\
\text { discussion or project(e.g., case } \\
\text { study work) }\end{array}$ & 0 & 0 & 0 & 1 & 0 & 1 & 0 & 0 & 2 \\
\hline 16 & $\begin{array}{l}\text { I had students complete a } \\
\text { problem solving game or } \\
\text { simulation in groups }\end{array}$ & 0 & 0 & 0 & 0 & 0 & 0 & 0 & 0 & 0 \\
\hline 17 & $\begin{array}{l}\text { I assigned individual student } \\
\text { presentations(e.g., speeches, } \\
\text { reports) }\end{array}$ & 0 & 0 & 0 & 0 & 0 & 0 & 0 & 0 & 0 \\
\hline 18 & $\begin{array}{l}\text { I assigned small group } \\
\text { presentations (e.g., debates, } \\
\text { panel discussions, plays) }\end{array}$ & 1 & 1 & 1 & 2 & 1 & 1 & 1 & 1 & 9 \\
\hline 19 & $\begin{array}{l}\text { I assigned a student-centered } \\
\text { class discussion(e.g., students } \\
\text { developed the questions and lead } \\
\text { the discussion that followed) }\end{array}$ & 0 & 0 & 0 & 1 & 0 & 1 & 1 & 1 & 4 \\
\hline 20 & I led a role playing activity & 0 & 0 & 0 & 0 & 0 & 0 & 0 & 0 & 0 \\
\hline
\end{tabular}


Table 4: The interactive teaching strategies used more during lecturing to large class at the last times.

\begin{tabular}{|c|c|c|}
\hline No. & Interactive Teaching Strategy & $\begin{array}{l}\text { Frequency of } \\
\text { using of } \\
\text { teaching } \\
\text { strategy in } \\
\text { total }\end{array}$ \\
\hline 1 & I lectured during the entire class period & 18 \\
\hline 2 & $\begin{array}{l}\text { I had students engage in a brainstorming activity(i.e., a group activity designed to generate } \\
\text { as many ideas as possible) }\end{array}$ & 16 \\
\hline 3 & $\begin{array}{l}\text { I led a class discussion focused on a visual/audio stimulus (e.g., a picture, cartoon, graph, } \\
\text { song) }\end{array}$ & 12 \\
\hline 4 & $\begin{array}{l}\text { I lectured with at least } 15 \text { minutes of time devoted to recitation or asking questions designed } \\
\text { to check student understanding of material (interaction between teacher-student/student- } \\
\text { teacher) }\end{array}$ & 10 \\
\hline 5 & I assigned small group presentations (e.g., debates, panel discussions, plays) & 9 \\
\hline 6 & $\begin{array}{l}\text { I lectured with at least } 15 \text { minutes of time devoted to class discussion (interaction between } \\
\text { student-student, with occasional questions/remarks by teacher) }\end{array}$ & 6 \\
\hline 7 & $\begin{array}{l}\text { I assigned a student-centered class discussion(e.g., students developed the questions and } \\
\text { lead the discussion that followed) }\end{array}$ & 4 \\
\hline 8 & During lecture, I gave a short, ungraded quiz to check student comprehension of material & 3 \\
\hline 9 & I took the class on a field trip & 3 \\
\hline 10 & I assigned a small group discussion or project(e.g., case study work) & 2 \\
\hline 11 & I showed a film or video for the entire class period. & 1 \\
\hline 12 & $\begin{array}{l}\text { I assigned a short writing activity without having class discussion afterward (e.g., writing } \\
\text { end-of-class summaries, providing questions over material) }\end{array}$ & 0 \\
\hline 13 & I had students complete a survey instrument & 0 \\
\hline 14 & $\begin{array}{l}\text { I had students complete a self-assessment activity (e.g., complete a questionnaire about } \\
\text { their beliefs, values, behaviors) }\end{array}$ & 0 \\
\hline 15 & I assigned a laboratory exercise that was done by students & 0 \\
\hline 16 & I assigned a short writing activity that was followed by at least 15 minutes of class discussion & 0 \\
\hline 17 & $\begin{array}{l}\text { I assigned an in-class reading activity that was followed by a significant class discussion } \\
\text { lasting } 15 \text { minutes or more }\end{array}$ & 0 \\
\hline 18 & I had students complete a problem solving game or simulation in groups & 0 \\
\hline 19 & I assigned individual student presentations (e.g., speeches, reports) & 0 \\
\hline 20 & I led a role playing activity & 0 \\
\hline
\end{tabular}

As seen in Table 4, the teaching strategy more used during lecturing at the last times resulted to be "lecturing during the entire class period" which was mentioned 18 times compared with other methods. Apart from difference that subjects had between them related to study areas, level of qualification, the years of university experience and the age, all of them show a strong approach to traditional lecture. 
The engagement of students in a brainstorming activity was ranked the second method more used in lecture, which was mentioned 16 times compared with other methods. Since this method includes active learning could be seen as an open attitude of university staff to embrace new methods promoting interactive learning during lecture.

One another good example introducing student activity into the traditional lecture was using of pause procedure with at least 15 minutes of time devoted to recitation or asking questions. This strategy was mentioned 10 times compared with other methods. The research has suggested that pause procedure can be done two or three times during an hour-long class. Because this is so simple, it provides a baseline to study whether short, informal student activities can improve the effectiveness of lecture.1

Small group presentations were also mentioned 9 times compared with others. There is consensus in the literature reviewed that group work is viewed as a meaningful and valued learning method. The value of group work is that students learn to function in groups. 2 Group work can help students to become more active in their learning. When working with peers in a group, students are encouraged to articulate their ideas and question the ideas of others. When it works, this leads to a social process of constructing ideas and developing possible solutions to problems. This active engagement with peers in learning should be more likely to lead to 'deep learning', in which students really understand the meaning of theories. 3

There were some kinds of activities that were using rarely during 3 last lectures, such as student-centered class discussion, checking student comprehension of material, field trip, using a film or video.

Meantime, there were some other activities that were hold of using during lecture, such as short writing activity without having class discussion afterward, completing of a survey instrument, self-assessment activity ore questionnaire, laboratory exercise during lecture, in-class reading activity, problem solving game or simulation in groups, individual student presentations.

Results of this study can indicate that using of interactive strategies during lecture trends to be sporadic, poor in choice and lower frequency.

It is a significant data that all subjects, apart from their difference in age, experience, qualification or study area, show a strong approach to traditional lecture. It seems that the traditional lecture method where lecturers talk and students listen, dominates in university classrooms yet.

\section{Conclusion}

The lecture is a component of pedagogic system that has been employed for hundreds of years in university institutions and it continues to be as well as a cornerstone 4 of higher education practices today.

The lecture is seen as making an efficient use of the lecturer's time, since it allow teaching to take place in classes with a very high student/staff ratio. The teaching through lecturing to large student groups is likely to become an increasingly compelling incentive in an era of declining resources. 5 European Union already has a quantitative goal that $40 \%$ of its young people should achieve higher education qualifications by 2020.6 This means that hereafter higher education institutions not only need to find places for more students than during this time, but also to adopt an more effective teaching and learning approach through lecturing in order that quality of those qualifications be ensured.

The research literature is robust that active learning can make a positive difference for university students. Implementing active learning in large lecture classes may seem intimidating. Nonetheless, incorporating active learning strategies does not mean that professors must completely abandon lectures, but they need to modify it. Rather, active learning techniques can be selectively incorporated into lectures to change the pace of the class 7 and reinforce students` learning process.

\footnotetext{
1 Prince, Michael (2004) .

2 Viki van Rensburg (May, 2012)

${ }^{3}$ Rob Watkins (2004)

44 John Sloman; Chris Mitchell; Peter Davies ( 2002 )

5 John Sloman; Chris Mitchell; Peter Davies ( 2002 )

${ }^{6}$ Graham Gibbs \& Trevor Habeshaw (2013)

7 Juan Carlos Huerta (2007)
} 
Thus, lecture to large class size trends to be a challenging experience for university teachers, in particular for the new lecturers. To ensure the teaching quality they need to know what pedagogical approaches to use during a lecture in large group, where to pitch the lecture, how to keep all students interested and which ways to employ to get students engaged.

Indeed, the incorporation of active learning strategies into the daily routine of lecturing to large class size is not an easy thing to done and not all professors can be expected to embrace it. Research has detected some of potential obstacles or barriers which interfere with this process. However, each type of risk can be successfully over-come if academics as university teacher develop a better understanding of teaching and learning issues in higher education as well as to advance their pedagogic competences.

Perhaps, most lecturers think of themselves as being good researchers make automatically them also good university teachers. Certainly, there are many good academics which may be using willingly teaching activities that are confirmed from research for their beneficial effects in university students` active learning process. But, in this point it is essential to make a distinction between teaching activities and teaching skills. Comprehensive teaching activities are not by themselves proof of demonstrated teaching skills. When judging teaching skills focus should be on to what extent the teacher has carried out the activities in such a way as to help improve student learning. 1

In the absence of educational development, teachers in higher education tend to base their teaching on their own experience as students. In this way, old teaching methods that focus on the teacher' rather than on the students' needs and on the subject matter rather than on the transformation of student knowledge perpetuate from generation to generation. 2

Generally, many countries in world, including Albania also, have perceived earlier the need for professional training of teachers at preschool, primary/elementary, secondary and high school level, whilst it seems to be a too common assumption that such professional teacher training is not necessary. According to European Science Foundation (ESF, 2012), teaching in higher education is still viewed as an activity that anyone can do. In many countries, academics are prepared for their role as research, but not for their teaching duties. 3

However, recent changes in higher education sector and increasingly request for the quality education make the development of academics' teaching skills a priority. In this framework, it is imperative to have a global collaboration and track down the recent experiences of countries such as, the United Kingdom, Ireland, Nordic and the Low Countries, United States, Australia and Canada, 4 in order that:

To define Professional Standards Framework for Teaching and Supporting Learning in Higher Education;

To establish teacher development programmes for academics and doctoral students;

To establish professional associations to advance teaching and learning in higher education.

\section{Limitations}

Even if questionnaires used in this study are generally known in evaluating the quality of teaching and active learning in higher education sector, they have a number of disadvantages compared with other evaluation tools. One of important characteristics of questionnaires is that they gauge opinion of participations rather than measure things more directly. This thing allows for some subjectivity in the responses obtained.

The full sample of participants which stand for academic staff included in study is shortage and this element can effect on generalizing of results.

\footnotetext{
1 Uppsala University (2014)

2 European Science Foundation (ESF) (November, 2012)

${ }^{3}$ European Science Foundation (ESF) (November, 2012)

${ }^{4}$ European Science Foundation (ESF) (November, 2012)
} 


\section{References}

Ann Morton (2009) "Lecturing to large group" A Handbook for Teaching and Learning in Higher Education - Enhancing Academic Practice, Third edition, Edited by Heather Fry, Steve Ketteridge, Stephanie Marshall, published by Routledge, 270 Madison Ave, New York, NY 10016.

Bonwell, Charles C., and James, A. Eison (1991) "Active Learning: Creating Excitement in the Classroom", ASHEERIC Higher Education Report No.1, George Washington University, Washington, D.C

Charles C. Bonwell (2000) "Active Learning: Creating Excitement in the Classroom" Active Learning Workshops

PO Box 407, Green Mountain Falls, CO 80819 (719) 684-9261, www.active-learning-site.com

Coffey, M. \& Gibbs, G. (2001) The evaluation of the Student Evaluation of Educational Quality Questionnaire (SEEQ) in UK higher education, Assessment and Evaluation in Higher Education, 26, 89-93.

Elaine Keane \& lain Mac Labhrainn (2005) Obtaining Student Feedback on Teaching \& Course Quality" Centre for Excellence in Learning \& Teaching, CELT.

European Science Foundation (ESF) (November, 2012) The Professionalization of Academics as Teachers in Higher Education, www.esf.org

Felder, R. (2007) Resources in Science and Engineering Education (website.) http://www.ncsu.edu/felder-publicl

Graham Gibbs \& Trevor Habeshaw (2013) Preparing to teach - An introduction to effective teaching in higher education; Report to the European Commission on improving the quality of teaching in Europe's higher education institutions

Instruction at FSU Handbook (2011) "Using Active Learning in the Classroom" Chapter 8

John Sloman; Chris Mitchell; Peter Davies ( 2002 ) The Handbook for Economics Lecturers

Juan Carlos Huerta (2007) Getting Active in the Large Lecture, Journal of Political Science Education, 3:237-249, 2007, Copyright \# 2007 Taylor \& Francis Group, LLC, ISSN: 1551-2169, DOI: 10.1080/15512160701558224

Meyer, C., \& Jones, T.B. (1993) "Promoting active learning: Strategies for the college classroom". San Francisco: JosseyBass.

Prince, Michael (2004) "Does Active Learning Works? A Review of the Research", Bucknell University, J. Engr. Education, 93(3), 223-231.

Richardson, J.T.E. (2005). Instruments for obtaining student feedback: A review of the literature. Assessment \& Evaluation in Higher Education, 30(4), 387-415

Rob Watkins (2004) Group work and Assessment, Handbook for Economics Lecturers, Kingston University.

Uppsala University (2014) Assessing Teaching Skills in Higher Education

Viki van Rensburg (May, 2012) Group assessment, EDU. 